\title{
Beyond Boundaries: Using Liquid Languages - Interview with Britta Schneider about "Liquid Languages"
}

Britta Schneider ${ }^{a}$

Konstanze Jungbluth ${ }^{b}$

\begin{abstract}
Data from plurilingual Belize shows that not everyone recognizes stability as an essential feature of a spoken language. Belizeans consider the use of Kriol as a symbol of belonging but foreground its readiness for variation across communities in space and time. Their use of liquid languages is a different form of cultural construction than the one our textbooks show. It questions a good part of linguistics and reveals its possibly Eurocentric point of view.
\end{abstract}

Keywords: Culture. Plurilingualism. language communities. Belonging.

\section{How to cite:}

Schneider, B.; Jungbluth, K. Beyond Boundaries: Using Liquid Languages - Interview with Britta 
Konstanze Jungbluth: As you know, there's an invitation from Gragoatá, and we want to make an interview in which you present your upcoming book. So I'm very curious about your concept of Liquid Languages rooted in plurilinguality. What's your research about?

Britta Schneider: The underlying question I have is: How do languages as separate categories come into being? Because we all very much live with this idea, particularly linguists, that there are different languages that exist like English or Portuguese or French or German and these are in a way treated as pre-given categories. And they are defined by a particular group of people who speaks this language and who also defines what is correct in this language and it is usually treated as something 'natural', so to speak, that simply exists. And now we have a lot of situations where people are multilingual and where communities themselves become multilingual. It's not only that we have different people who come from different language communities, but the communities themselves are multilingual. So I decided to study a highly multilingual language community in Belize, Central America, and the question of this study on a very complex language situation was: How are languages constructed, how do they come into being in highly diverse settings where there is a lot of language contact and where we have a lot of multilingualism - where it wouldn't be easy to say what is the community and who speaks the language.

KJ: Please, tell us more about Belize and the conviviality of languages spoken there!

BS: Can you tell me what your definition of conviviality is at this point?

KJ: I was taking it from a scholar of Social Sciences, Magdalena Nowitzka (DeZiM, Berlin). It is a term, which refers to the language multiplicity in Alfonso el Sabio's Court in the $14^{\text {th }}$ century in southern Spain. One is very impressed by the multitude of languages spoken and the social practice of conviviality of religions and culture in that place.

BS: Also, in the sense that the different religions, cultures, languages live together peacefully? 
KJ: Yes, that's the point.

BS: Yes, so the question you ask is about: What is the linguistic situation in Belize? Of course, it's extremely complex, which has to do with the social history of the country. It is a very, very small country in the Caribbean, but it's not an island. It is a country bordering with Guatemala and Mexico. It used to be a British colony but the majority of the population speaks Spanish as one of their languages. English is the official language of the country, so officially it's an 'English-speaking country', but almost no one speaks English at home.

And then we have this language called Kriol, which is a language that developed in times of slavery, which is very roughly speaking a mix of English and the previous languages of the slaves, so it's English-lexified, that means the vocabulary is English mostly, but the grammatical structures have developed in that situation of extreme language contact in times of slavery.

There is still impact from African language, so there's still a lot of structures that are very different from English. Furthermore, language ideology, that is concepts people have about language, as I have found out in my research, is very different from Western normative language cultures. So people do not usually write Kriol and they do not have as much the idea that stability and non-changing language is something good. It's rather the opposite that people think language change is something positive, it shows your creativity and they actually reject the idea of making it stable and develop one standard.

Kriol language and culture is a very important thing in Belize. Not only because it's interesting from a linguistic point of view, but also because it is what the people identify with. And it's the language that people understand to be the language of Belize. So even though English is the official language, if you speak Kriol you are considered Belizean. Even if you speak Spanish at home, you have to speak Kriol on the streets and to your friends to show that you're really Belizean and not an immigrant, because there are also a lot of Spanish immigrants besides the native Spanish population. On top of that there are a lot of other languages like the various traditional Maya languages Mopan, Q'eqchi', Yucatec, and there's Hindi, because of indentured slavery. There's a lot of 
German speakers, but they are the only ones who actually do not mix with anyone else.

Nowadays there are quite a lot of other languages from Europe because a lot of other people also migrate there in like a luxury migration, people who have money or buy a hotel or something there. There are a lot of Italians and Germans and Polish, so it's very, very mixed and very complex, and I think for the question of how do languages come into being, it's particularly interesting to look at the relationship between English, Spanish and Kriol in that situation.

KJ: Yeah, so you have a trilingual setting at the base or at least many people who have access to these three languages, and this makes the choices in the situation very meaningful. In which sense are these choices a symbol of belonging? You told us that Kriol is the Belizean language, what about the home languages and the officially recognized English?

BS: This is where it becomes really complex. I actually also avoided to classify people according to their home language because a lot of people have troubles to identify what their home language is, because they really use mixes of these languages. And often people say "Oh I don't speak Spanish", but then they do. Or they do not perceive themselves to be Spanish speakers, for example, so asking people about "What is your home language?", it's actually very clear in that context that it is a highly ideological and loaded question on how you perceive yourself. It's really not necessarily telling about what you actually do and what your language practice is. But there is a strong tendency that English is the language for formal contexts, it's the language for education and for news broadcasts, for example, and the language of writing, and it has, of course, prestige as a "real" language with a "real" standard - in contrast to how Kriol is perceived - and it's embedded in this whole colonial history as the language of the powerful group. Nowadays, it's also the language of the US and their close ties. And then Kriol, as I said, is the symbol for being Belizean, at the same time it's also more associated with informality, with lower classes, with verbal play and it's also not really standardized, and people very openly tell you that it can be different from village to village. So it's not one practice, but it's an idea of liquid practices. 
KJ: But there is some writing in Kriol as well, isn't it?

BS: There is writing, but this is not an everyday practice. I mean, it is turning into an everyday practice in online settings like on Facebook or Twitter or so. There is an orthography that has been developed, and there are language activists who strongly support this writing, but they are not very popular and they are not very successful.

KJ: Therefore... for not being popular they are not successful! BS: And they are actually funded by US-American Christian Bible people.

KJ: Ah, I see. As in other places in Latin America they play an important role.

BS: Of course, there is a strong point to standardize the language, but it's very ambivalent, because most people I spoke to they do not want there to be a Kriol standard and they do not use the standard developed by language activists. They do not use the standard, not when they write on Facebook or on Twitter or something, they do not identify with this standard.

KJ: Well, do you think that in global times the social practices, particularly the plurilingual language use may be experienced at other places and transferred to other countries?

BS: Oh, yes, definitely! In a way, I went to Belize because I believe that it's a kind of avant-garde place for developments that will occur in other places and that the language situation will become much more complex also elsewhere. I mean, if you look at Germany, for example, we have English now as one language for formal academic discourse, it's totally normal. I mean, you and me we sit here and speak English, both located in Germany. And it's not that languages still have the symbolic function so much as indexing the territorial place, but all the languages have other functions besides symbolizing national belonging, like class, smaller communities or trans-national communities. I think it will be very useful at languages not simply as territorial national languages, but to look at the respective local language ideologies, as I have done in Belize. We have to take into account language ideologies, social spaces and the cultural practices associated with particular languages to understand what is going on. And, of course, 
digital communication here plays a very important role in these changes.

KJ: I agree totally. Taking your stance, which lessons can we learn?

BS: Oh, many lessons! I think, first of all, I think for me an important lesson that I find theoretically relevant is the understanding that the existence of languages is not something natural, but that it depends on cultures of sedentariness and stability. It's not that I want to say we do not have languages, there are languages and they develop under particular social and technological conditions. Political situations, like nationstates that are rather stable and define who their population is and how they behave culturally, plus cultures of the printing press, are co-responsible for these ideas that languages are stable systemic entities. This is one thing that we can learn: to look at our own epistemological histories and our own thoughts of language, how much are they framed by our own socio-cultural practices and technological practices? Secondly, from a social point of view, it is important to look at cultures that are more and more globalized. There's a lot of discrimination against people who do not conform to standards of language. Liquid language uses are part of normal everyday culture and should not be stigmatized. And we should think about what we can do to no longer exclude those who do not conform to particular cultures of standard. At the same time, we still have to teach standards because they are still such important powerful symbols of belonging in our cultures. But I think we should get used to the fact that people use different orthographies, maybe have different accents and no longer believe that everyone who does not know where to use which letter in all cases or has, what we call, a "foreign accent" should be excluded from discourses and positions of power.

KJ: Finally, my last question is: Do you consider the scenario you did explore at Belize as one being marked by our times or do we have to reconsider earlier research in linguistics concerning language contact in the history of mankind in this light?

BS: Yes, I very much think that this perspective is very important in also reconsidering the history of linguistics, for 
example, looking critically at which point developed the idea that languages are simply there, and systemic stable constructs, when does that emerge in the history of linguistics? Also, critically question the development of linguistics, particularly historical-comparative linguistics in the 19th century in relation to the discourses of nationalism that existed at the time. That would be a very interesting and I think relevant research, like a meta-scientific exploration of these things.

And then it would also be interesting to look at other $19^{\text {th }}$ century scholars who have different ideas about language, like Hugo Schuchardt, for example, and you can think about why that is so. And you can also think about why it is that in $20^{\text {th }}$ century linguistics you have this very strong dominance of systemic structural linguistics to an extent that many people, even in academia, believe that "real linguistics" is if you study stable syntactical structures, or try to find universal grammar and things like that. They completely deny that there are social conditions for stable grammars to exist, for example. Instead they believe that it is a "natural" biological thing. I think there's a lot of opportunity to use the perspective to also critically question the discipline of linguistics. I also think even if you still have the aim to look at stable grammars - because I'm not saying there are no grammars - I think it's particularly fruitful to understand stable (or rather, relatively stable) grammars against the background of "what are the social conditions that allow for particular forms of stabilization" and "what are the technological conditions and how does digital language practice interact with these social conditions". I think there's a lot of potential and I think it will still be important to of course look at grammatical structures, but not understand them as a biological thing in your brain.

KJ: This brings me back to the point of technological possibilities. So, in my view, of course linguistics, which came out of philology, is very connected with culturally highly prestigious forms of writing and this makes the language stable. If you see before Gutenberg and after Gutenberg, you see that the manuscripts change in their way of diversity, in their way of divergence. And this is maybe a point where one can see that the modern possibilities are different and that 
helps in a certain way to get a picture of the diversity which is still present in spoken language use. Do you agree in that? BS: Yes, and of course it's also interesting to study maybe whether there are parallels in the way people before Gutenberg used written language and how they do it now in, for example, a digital chat. Also, written language can have very different functions that we traditionally associate with it: functions of formal interaction and social distance. We have this traditional idea that writing is associated with social distance and formality - and now we see that this is actually not a necessity, that it is just the culture. And I think this is like my main point I want to make, or one of the important things, in my research agenda: to emphasize that language is culture and not biology.

KJ: Thank you very much, Britta Schneider.

BS: My pleasure.

September 15, 2020 


\section{Resumo}

Além das fronteiras: o uso de línguas fluidas - Entrevista com britta schneider sobre o uso de línguas fluidas

Dados referentes ao país plurilingue Belize mostram que a estabilidade não é unanimemente reconhecida como um traço essencial da lingua falada. Belizenses usam o Kriol como simbolo de pertencimento mas valorizam a sua disponibilidade para a variação entre as comunidades de fala no espaço e no tempo. O seu uso de línguas fluidas representa uma construção coletiva bem distinta da forma tratada nos nossos manuais. Essa perspectiva questiona boa parte da linguística e revela um possível ponto de vista eurocêntrico.

Palavras-chave: Cultura. Plurilinguismo. Comunidades da Fala. Pertencimento.

Britta Schneider é Doutora pela EuropaUniversität Viadrina (Frankfurt-Oder). Professora na área de Linguagem e Migração nessa universidade. Membro da Cooperação Europeia em Ciência e Tecnologia (COST). Desenvolve pesquisas na área da sociolinguística, com ênfase em atitudes e ideologias linguísticas, etnografia linguística e política de linguística.

Konstanze Jungbluth é Decana da Faculdade de Estudos Culturais da EuropaUniversität Viadrina (Frankfurt-Oder); professora de Pragmática e de Linguística comparada. Especialista em Pragmática da línguas românicas, estuda a relação entre formas linguísticas e modalidades textuais, escritas e orais. Participa do Projeto "Multilinguismo, direitos linguísticos e desigualdade social" (CAPES-PrInt-UFF). 